\author{
®Н. І. Макєєва, В. М. Цимбал \\ Харківський національний медичний університет

\section{КЛІНІЧНЕ ЗНАЧЕННЯ РІВНІВ ВІТАМІНУ D У КРОВІ ДІТЕЙ ІЗ ЦУКРОВИМ ДІАБЕТОМ 1 ТИПУ}

КЛІНІЧНЕ ЗНАЧЕННЯ РІВНІВ ВІТАМІНУ D У КРОВІ ДІТЕЙ ІЗ ЦУКРОВИМ ДІАБЕТОМ 1 ТИПУ. У статті наведенО результати дослідження рівня вітаміну D у крові 42 дітей із цукровим діабетом 1 типу та 15 дітей контрольної групи. Виявлено достовірне зниження показників вітаміну D (недостатність, дефіцит) у крові дітей із цукровим діабетом 1 типу порівняно з групою контролю, а також зв'язок між дефіцитом або недостатністю вітаміну D та розвитком діабетичної нефропатії.

КЛИНИЧЕСКОЕ ЗНАЧЕНИЕ УРОВНЕЙ ВИТАМИНА D В КРОВИ ДЕТЕЙ С САХАРНЫМ ДИАБЕТОМ 1 ТИПА. В СТаТЬЕ представлены результаты исследования уровня витамина D в крови 42 детей с сахарным диабетом 1 типа и 15 детей контрольной группы. Выявлено достоверное снижение показателей витамина D (недостаточность, дефицит) в крови детей с сахарным диабетом 1 типа в сравнении с группой контроля, а также связь между дефицитом или недостаточностью витамина D и развитием диабетической нефропатии.

CLINICAL SIGNIFICANCE OF VITAMIN D IN BLOOD FOR CHILDREN WITH DIABETES TYPE 1. The article presents research results of vitamin $D$ blood levels in 42 children with type 1 diabetes and 15 children from control group. A significant decline of vitamin D blood levels (insufficiency, deficiency) in children with Type 1 diabetes compared with the control groupand the relationship between deficiency or insufficiency vitamin $D$ and the development of diabetic nephropathy were determined.

Ключові слова: цукровий діабет, діабетична нефропатія, вітамін D, діти.

Ключевые слова: сахарный диабет, диабетическая нефропатия, витамин D, дети.

Key words: diabetes mellitus, diabetic nephropathy, vitamin D, children.

ВСТУП. За даними Всесвітньої організації охорони здоров'я (ВООЗ), у світі нараховується більше одного мільярда людей, які мають дефіцит чи недостатність вітаміну D. Сучасні наукові уявлення про біологічну роль вітаміну D в організмі в останні роки вивчало багато вчених, що дозволило істотно змінити погляди на його фізіологічну роль. На рівні геному метаболіти вітаміну D виявляють свій фізіологічний ефект, схожий за дією до стероїдних гормонів [1]. Експериментальними дослідженнями встановлено, що вітамін D бере участь у проліферації та диференціації клітин різних органів і тканин, у процесі імунної відповіді, функціональної активності серцево-судинної системи, шлунково-кишкового тракту, клітин кісткової та м'язової тканин [2]. Крім того, вітамін D має профілактичний ефект відносно розвитку діабету. Науковці зі США з'ясували наявність взаємозв'язку між концентрацією вітаміну D у сироватці крові людини та розвитком у неї цукрового діабету (ЦД) 1 типу. Достатній рівень вітаміну $D$ у молодому віці може знизити ризик розвитку в майбутньому ЦД на $50 \%$ [3, 4].

Дослідження на тваринах показують, що вітамін D також впливає на нирки, а саме: має виражену протизапальну дію, знижує протеїнурію, стримує прогресування гломерулярного та тубулоінтерстиціального фіброзу, послаблює продукування фіброгенних цитокінів та запобігає гіпертрофії клубочків. Крім того, вітамін D гальмує активність ренін-ангіотензинової системи, яка стимулює продукування цитокінів, що сприяють розвитку нефросклерозу та є головним медіатором прогресування діабетичної нефропатії (ДН) [5]. За даними різних авторів, від 30 до 50 \% пацієнтів, які захворіли на ЦД у дитячому віці, помирають від ниркової недостатності [6, 7]. На цей час наявні поодинокі роботи, які експериментально доводять позитивний ефект вітаміну D на прогресування хронічної ниркової недостатності. Вітамін D-статус у дітей, клінічне значення та ренопротекторна дія вітаміну D у хворих на ЦД 1 типу дітей недостатньо вивчені.

Мета дослідження - дослідити рівень вітаміну D y дітей із цукровим діабетом 1 типу та з'ясувати наявність зв'язку його рівня з формуванням ДН.

МАТЕРІАЛИ ТА МЕТОДИ. Обстежено 42 дитини (22 хлопчики та 20 дівчаток), хворих на ЦД 1 типу, віком від 6 до 17 років. Діти були поділені на групи: 1 -ша група ( $\Pi=24$, середній вік $14,64 \pm 1,63$ року) хворі $з$ тривалістю цукрового діабету більше 5 років та нормоальбумінурією, 2-га група ( $п=18$, середній

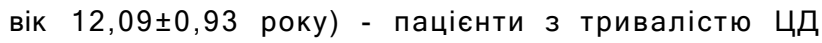
більше 5 років та ДН у стадії мікроальбумінурії (МАУ). До групи контролю включено 15 практично здорових дітей аналогічного віку, які не мали скарг, клінічних ознак, анамнестичних даних, які б свідчили про наявність будь-якого хронічного захворювання протягом останніх двох місяців гострих. Для обстеження дітей використовувалися загальноприйняті методи згідно з протоколом обстеження дітей за спеціальністю «Дитяча ендокринологія» (наказ МО3 України № 254 від 27.04.2006р.). Визначали рівні глікозильованого гемоглобіну (НЬА1с), МАУ, креатиніну та сечовини крові, швидкість клубочкової фільтрації (ШКФ). Визначення рівня МАУ в добовій сечі проводили шляхом осадження поліетиленгліколю комплексом «антиген-антитіло» методом кінцевої 


\section{Педіатрія}

точки за допомогою стандартного набору виробництва «ISES» (Італія). Визначали ШКФ розрахунковим методом, за формулою Шварца. Рівень вітаміну D y крові визначали за допомогою імуноферментного аналізу з використанням комерційного набору "25OH Vitamin D ELISA AssayKit» фірми «EagleBiosciences, Inc.» на імуноферментному аналізаторі «LabLine-90».

Статистичний аналіз даних проводили за допомогою статистичних пакетів EXCELL FOR WINDOWS та STATISTICA 7.0. FOR WINDOWS. 3 метою характеристики групи для ознак з розподілом відповідно до закону Гаусса визначали середнє арифметичне значення (X), його статистичну похибку (SX), стандартне відхилення (S). Для вибірок з розподілом, що відрізняється від нормального, визначали медіану (Me) та інтерквартильний розмах (Lq - нижній квартиль; Uq - верхній квартиль). Для порівняння двох вибірок використовували непараметричний U-критерій Манна-Уїтні (MW). Різницю параметрів, що порівнювали за двома точками, вважали статистично значущою при $p<0,05$. При порівнянні показників, які характеризувалися порівнянням більше 2 точок, використовували Н-критерій дисперсійного аналізу Краскела-Уолліса (KW), а відмінності вважали вірогідними з урахуванням поправки Бонферроні. Ризик виникнення події розраховували за допомогою $\operatorname{RR}($ відносний ризик) 3 вказівкою $95 \%$ інтерва- лу. Для визначення функціональної залежності між кількісними та якісними показниками використовували процедуру логістичної регресії. Для оцінки сили зв'язку між чинником та виходом застосовували нормоване значення коефіцієнта Пірсона ( $\left.C^{\prime}\right)$, а інтерпретацію одержаних значень статистичних критеріїв проводили згідно 3 рекомендаціями «Rea\&Parker».

Клінічне дослідження схвалила Комісія з питань етики та біоетики Харківського національного медичного університету. Всі учасники та їх батьки дали письмову інформовану згоду.

РЕЗУЛЬТАТИ ДОСЛІДЖЕННЯ ТАЇХ ОБГОВОРЕННЯ. У дітей всіх груп виявлена тривала гіперглікемія, що підтверджує високий рівень $\mathrm{HbA1c}$, без групових відмінностей (всі р>0,05) (табл. 1). При обстеженні встановлено, що у $33 \%$ пацієнтів 1-ї групи та 44 \% хворих 2-ї групи має місце зниження ШКФ (104 (69; 124) та 106 (77; 117) мл/хв відповідно), що, вочевидь, пов'язано з виснаженням фізіологічних компенсаторних механізмів та прогресуванням ДН, ще до появи МАУ. При дослідженні МАУ відзначено статистично значуще підвищення цього показника у дітей 2-ї групи порівняно з 1 -ю групою пацієнтів $(46,8(55,6$; $77,4)$ та $11,9(7,0 ; 19,7)$ мг/добу відповідно $(p<0,001))$. Результати вивчення показників перебігу ЦД 1 типу наведено в таблиці 1 .

Таблиця 1. Статистичні характеристики деяких показників перебігу ЦД

\begin{tabular}{|c|c|c|c|c|}
\hline \multirow{2}{*}{ Показник } & \multirow{2}{*}{$\begin{array}{c}\text { Статистичний } \\
\text { показник }\end{array}$} & \multicolumn{2}{|c|}{ Діти, хворі на ЦД 1 типу } & \multirow[b]{2}{*}{$P$} \\
\hline & & 1-ша група $(n=24)$ & 2-га група $(n=18)$ & \\
\hline Тривалість ЦД, роки & $\mathrm{X} \pm \mathrm{Sx}$ & $7,32 \pm 0,52$ & $9,23 \pm 0,69$ & ${ }_{.}^{.}=0,07632$ \\
\hline HЫAс, \% & $\begin{array}{l}\mathrm{Me} \\
\mathrm{Lq} \\
\mathrm{Uq}\end{array}$ & $\begin{array}{l}8,28 \\
7,45 \\
9,32\end{array}$ & $\begin{array}{l}8,65 \\
7,98 \\
9,82\end{array}$ & $\mathrm{p}^{\wedge} 2=0,6329$ \\
\hline ШКФ, мЛ/хв & $\begin{array}{l}\mathrm{Me} \\
\mathrm{Lq} \\
\mathrm{Uq}\end{array}$ & $\begin{array}{c}104 \\
69 \\
124\end{array}$ & $\begin{array}{l}106 \\
77 \\
117\end{array}$ & $\mathrm{Pi}-2=0,1101$ \\
\hline МАУ, мг/добу & $\begin{array}{l}\mathrm{Me} \\
\mathrm{Lq} \\
\mathrm{Uq}\end{array}$ & $\begin{array}{l}11,9 \\
7,0 \\
19,7\end{array}$ & $\begin{array}{l}46,8 \\
55,6 \\
77,4\end{array}$ & $p^{\wedge} 2=0,0000$ \\
\hline
\end{tabular}

Після проведеного аналізу статистичних характеристик множинного порівняння показника вітаміну D у крові зазначимо, що Н-критерій КраскелаУолісса високозначущий, а саме: $\mathrm{H}=26,53789$, $\mathrm{p}=0,0000$. Це дає право стверджувати, що статистичні характеристики різних груп статистично значуще відрізняються між собою, а рівень лабораторних показників, що досліджувалися, залежить від належності пацієнта до тієї чи іншої групи.

Дослідження вмісту вітаміну D у крові виявило статистично значуще зниження його рівня у дітей 1-ї та 2-ї груп $(22,03(17,23 ; 24,44)$ і 14,42 $(12,02$; $19,63)$ нг/мл відповідно) порівняно з групою контролю $(30,65(28,45 ; 35,05)$ нг/мл, р<0,001) (рис. 1). Згідно з рекомендаціями ВООЗ та загальноприйнятими класифікаціями, рівень 25(OH)D у сироватці крові 30 нг/мл і більше розцінювали як достатній, вітамін D у межах 20-29 нг/мл - як недостатність, рівень менше 20 нг/мл - як дефіцит вітаміну D. Встановлено, що показники вітаміну D у крові були

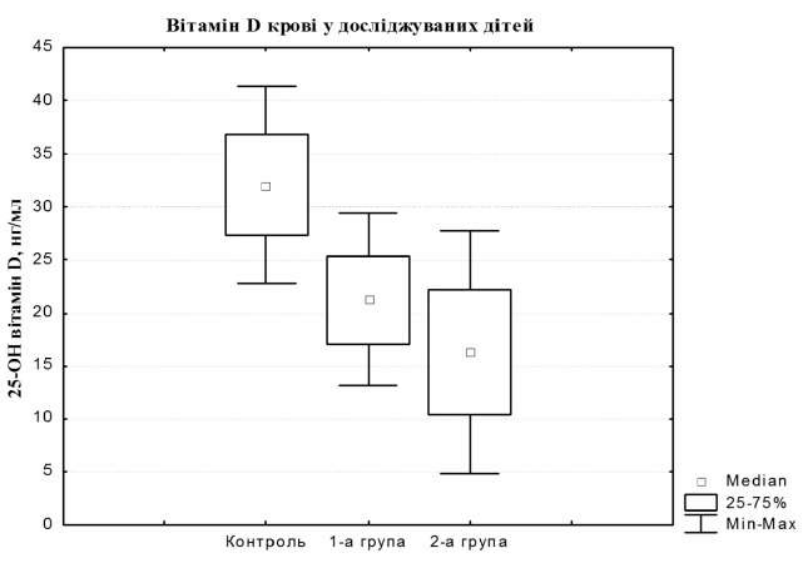

Рис. 1. Рівні вітаміну D у крові дітей із ЦД 1 типу та контрольної групи. 


\section{Педіатрія}

достовірно нижчими в пацієнтів 3 ДН порівняно 3 дітьми 3 нормоальбумінурією $(p=0,0056)$. Також відзначено, що питома вага пацієнтів з мікроальбумінурією, які мають дефіцит вітаміну D, статистично значуще вища, ніж дітей без ДН (77,8 \% проти $41,7 \%, p=0,0244)$. З'ясовано, що діти з ЦД 1 типу та дефіцитом вітаміну D мають ризик формування ДН у 2,6 раза вищий, ніж пацієнти 3 ЦД без дефіциту вітаміну $D\left(R R=2,625[1,048 ; 6,640], x^{2}=4,102, p<0,05\right)$. А зв'язок між дефіцитом вітаміну D та розвитком ДН був розцінений як відносно сильний $\left(C^{\prime}=0,48\right)$. Процедура логістичної регресії підтверджує, що недостатність $(O R=1,84, p<0,05)$ та дефіцит вітаміну $D$ $(\mathrm{OR}=2,94, \mathrm{p}<0,05)$ пов'язані з наявністю ДН, віком, статтю, тривалістю діабету та рівнем глікемічного контролю.

\section{СПИСОК ЛІТЕРАТУРИ}

1. Vitamin $D$ receptor and its protective role in diabetic nephropathy / X. Guan, H. Yang, W. Zhang [et al.] // Chin. Med. J. - 2014. - Vol. 127(2). - P. 365-369.

2. Lower prediagnostic serum 25-hydroxyvitamin D concentration is associated with higher risk of insulinrequiring diabetes: a nested case-control study / E. D. Gorham, C. F. Garland, A. A. Burgi [et al.] // Dabetologia. - 2012. - Vol. 55. - P. 3224-3227.

3. The association between ultraviolet $B$ irradiance, vitamin $D$ status and incidence rates of type 1 diabetes in 51 regions worldwide / S. B. Mohr, C. F. Garland, E. D. Gorham [et al.] // Diabetologia. - 2008. - Vol. 51. P.1391-1398.
ВИСНОВКИ. Таким чином, одержані результати демонструють вірогідне зниження показників вітаміну D (недостатність або дефіцит) у крові дітей із цукровим діабетом 1 типу. Встановлено наявність статистично значущого сильного зв'язку між дефіцитом або недостатністю вітаміну D та розвитком ДН.

ПЕРСПЕКТИВИ ПОДАЛЬШИХ ДОСЛІДЖЕНЬ. ПОтребують подальшого вивчення ефекти метаболітів вітаміну D на формування та прогресування ДН у дітей. Вважаємо доцільним дослідження рівня вітамін Dзв'язуючого білка порівняно з іншими показниками пошкодження тубулярного апарату нирок при ЦД. Перспективним $є$ дослідження особливостей метаболізму сполучної тканини у дітей з ЦД, що дозволить вивчити механізми формування ДН та обґрунтувати профілактичні засоби ренопротекції.

4. Vitamin $D$ levels in subjects with and without type 1 diabetes residing in a solar rich environment / L. Bierschenk, J. Alexander, C. Wasserfall[et al.] // Diabetes Care. - 2009. - Vol. 32. - P.1977-1979.

5. Risk assessment for vitamin D / J. Hathcock, A. Shao, R. Vieth, R. Heaney // Am. J. Clin. Nutr. - 2007. Vol. 85. - P. 6-18.

6. Diabetic nephropathy: mechanisms of renal disease progression / Y. S. Kanwar, J. Wada, L. Sun [et al.]. E. Biol. Med. - 2008. - Vol. 233(1). - P. 4-11.

7. Иванов Д. Д. Диабетическая болезнь почек / Д. Д. Иванов // Клиническая практика. - 2008. № 3 (24). - С. 86-88. 